\title{
THE LAST DECADES OF THE EXISTENCE OF THE KAUNAS BERNARDINE NUNS (1842-1864)*
}

\author{
Vaida Kamuntavičienè \\ (Vytautas Magnus University)
}

\begin{abstract}
This article reveals the life of the Holy Trinity Bernardine nuns in Kaunas (Kowno) in the years 1842 to 1864, the worsening situation at the convent due to the Russian occupying government's policy, the actual closure of the convent, and the fate of the nuns after the closure of their home. The study aims to show how daily life at the convent affected the Russian administration's decisions regarding its material provision and particular nuns living there, how they were affected by the closure of St George's Bernardine Friary in Kaunas which used to be the main supporter of the Bernardine nuns, and relations between the Bernardine nuns and the bishop. The author analyses difficulties in community life and problems adhering to the constitution, and reveals the general mood of the nuns. The research is based on correspondence between the Bernardine nuns, the bishop and the convent visitator, memoirs, and material from visitations. This case study of the Kaunas Bernardine nuns helps us gain a better understanding of the situation of the Catholic Church in the Russian Empire.
\end{abstract}

KEYWORDS: Kaunas (Kowno) Bernardine nuns, Kaunas (Kowno) Bernardine friars, convent closure, Maciej Wołonczewski (Motiejus Valančius), 19th century.

\section{Introduction}

Historians have written about Imperial Russia's policies towards the Catholic Church in Lithuania in the 19th century and the closure of monasteries and convents. ${ }^{1}$ Algimantas Katilius has shown that between 1798 and 1915, of the 29 convents in the dioceses of Vilnius and Samogitia (Telšiai), only five evaded

" This article was written with support from the Research Council of Lithuania, project No S-LIP-2O-17.

${ }^{1}$ R. Laukaitytè, Lietuvos vienuolijos. XX amžiaus istorijos bruožai (Vilnius, 1997); Krikščionybès Lietuvoje istorija, ed. V. Ališauskas (Vilnius, 2006). 
closure. ${ }^{2}$ However, most historians limit themselves to research into the occupying government's decrees and general statistical information. There is still not enough research into specific convents, resolutions, and the daily life of nuns facing this inevitability. In his writing about the fate of Franciscan friars in West Prussia who ended up in the Kingdom of Prussia after the First Partition of the Polish-Lithuanian Commonwealth in 1772, Wojciech Zawadzki has drawn attention to the material deprivations that befell the monks, the sense of despair, indignity and loneliness, and the loss of their sense of security, knowing that an injustice had been done, and that hope and sometimes even honour had been taken away from them. ${ }^{3}$

The case of the closure of the Bernardine convent in Kaunas (Kowno) ${ }^{4}$ has been chosen for this study, which allows us to take a close look at the situation there. In 1618, the Marshal of Kaunas, Aleksander Massalski, and his wife Apolonia Jasińska-Massalska, sponsored the founding of the Bernardine Convent of the Holy Trinity in Kaunas. They only had one daughter, Klara, who devoted her solemn loyalty to the Lord, professed her vows at this Kaunas convent, and ended up bequeathing practically all of their land to the institution, the basis of which was the Zapyškis folwark. This funding led to the construction of the Church of the Holy Trinity and Convent some time before 1634 . The Bernardine convent and the Benedictine convent funded by Andrzej Skorulski (1624) were the only two convents in the city of Kaunas. In the years 1825 to 1867 , the Sisters of Charity also lived in Kaunas. A constitution (regula) for the Bernardine nuns in the Grand Duchy of Lithuania was printed in $1740,{ }^{5}$ which was intended to help the nuns

${ }^{2}$ A. Katilius, 'Moterų vienuolynų tinklas buvusios Lietuvos Didžiosios Kunigaikštystės žemėse XVIII a. pabaigoje - XX a. pradžioje', in: Lietuvos Didžiosios Kunigaikštystès moteru vienuolijos: istorija ir paveldas, ed. A. Vasiliauskienė (Kaunas, 2014), p. 34.

${ }^{3} \mathrm{~W}$. Zawadzki, 'Losy franciszkanów w Prusach Zachodnich w okresie kasaty ich klasztorów', in: Hereditas monasteriorum, 2 (Wrocław, 2013), p. 95.

${ }^{4}$ In the Polish-Lithuanian Commonwealth, the 'Bernardines' was the name given to members of the Third Order of St Francis, who functioned under the guardianship of the Observant Lesser Brothers (Bernardine friars).

${ }^{5}$ Regulamen zakonny, albo Konstytucye panień zakonnych Prowincyi W. X. Litewskiego, swiętego Kazimierza Zakonu świętego Franciszka, z rożnych statutow general- 
organise their daily life, so that thy could fulfil their vocation as well as possible.

After the partition of the Polish-Lithuanian Commonwealth in 1795, Kaunas ended up incorporated inteo the Russian Empire, while the Bernardine nuns' main Zapyškis estate ended up in the territory of the Kingdom of Prussia. In 1797, the Remezov estate in the Bieniakoni parish in the Ashmyany powiat (present-day Belarus) was given to them as compensation; but it was far away, the soil was stony and infertile, and the folwark required significant investment. ${ }^{6}$ The wave of convent and monastery closures that followed the 1830-1831 uprising against the Russian occupation brought a sense of anxiety to the Kaunas community of Bernardine nuns as well. Everything changed further in 1842, when, according to an imperial decree, monasteries and convents were divided into those that received funding from the state and those that did not, and the latter faced the very real threat of closure. Even though the Bernardine convent in Kaunas had been put in the highest (first) category, and was not threatened with closure, they could never be sure the situation would not suddenly change.

There was a set number of mandatory nuns (19), and its land holdings were confiscated. The Kaunas Bernardine nuns were left with only 150 dessiatins (approximately 163.5 hectares) of the Virbaliūnai folwark, and an allowance of 2,765 roubles was allocated from the Treasury for their maintenance, which was barely enough to satisfy their most basic needs. After the reform of the diocesan network in 1848, Kaunas, which had hitherto belonged to the Diocese of Vilnius, was assigned to the Diocese of Samogitia (Telšiai). The Bernardine Friary of St George, which had supported the Kaunas Bernardine nuns since its founding,

skich, y prowincyalskich; z wielu także dekretow papieskich generalnie zebrane, potym zupetna wtadza od Kapituty Generalskiey w Hiszpaniey korrygowane, konfirmowane, y do zachowania tymże pannom zakonnym podane (W Supraslu: w drukarni WW. OO. Bazylianow, 1740), p. 35 .

${ }^{6}$ Visitation of the Kaunas Bernardine convent, 31 July 1820, Lithuanian State Historical Archives (Lietuvos valstybės istorijos archyvas, henceforth LVIA), col. 691-1-3669, p. 357; Visitation of the Kaunas Bernardine convent, 1818, LVIA, col. 694-1-4014, pp. 670v-671; J. Oksas, 'Buvusio bernardiniu vienuolyno ansamblio Kaune (dab. Tarpdiecezinè kunigu seminarija) istoriniai tyrimai', in: Kauno istorijos metraštis, 1 (Kaunas, 1998), p. 219. 
was abolished in $185^{\circ}$, and they came under the jurisdiction of the Bishop of Samogitia (Telšiai). So began the most difficult stage in the life of the Kaunas Bernardine nuns, which culminated in the convent's closure in $\mathbf{1 8 6 4}$.

The purpose of this article is to present the life of the Kaunas Bernardine nuns in the years 1842 to 1864 . I try to show how daily life at the convent was affected by the Russian administration's decisions regarding their material provision, the composition of the nuns at the convent, how they were affected by the closure of the Bernardine friary, and the relationship between the Bernardine nuns and the bishop, and also to show their adherence to the solemn vows, the difficulties in community life, the closure process, and the fate of the sisters after the abolishment of their home. This case study of the Kaunas Bernardine nuns can help deepen our understanding of the situation faced by Catholic monasteries and convents that had suddenly become part of the Russian Empire.

The study is based on 19th-century Kaunas Bernardine convent visitation acts and inventories. ${ }^{7}$ These documents, compiled according to a standard survey, convey a rather accurate picture of the institution's material situation and statistical information; however, they give a poor reflection of the daily life. Other important sources in this research are the correspondence between the Kaunas Bernardine convent and the Bishop of Samogitia (Telšiai) Maciej Wołonczewski (Motiejus Valančius), the bishop's Chancellery, documents written by the monastery and convent visitator Marcjan Giedroyć (Giedraitis), ${ }^{8}$ the memoirs written by

\footnotetext{
${ }^{7}$ Visitation of the Kaunas Bernardine convent, 7 June 1804, Kaunas Archdiocese Curia Archive (Kauno arkivyskupijos kurijos archyvas, henceforth KAKA), file 142, pp. 848-854v; Visitation of the Kaunas Bernardine convent, 1818, LVIA, col. 694-1-4014, pp. 669-673; Visitation of the Kaunas Bernardine convent, 31 July 1820, LVIA, col. 694-1-3669, pp. 324-358v; Visitation of the Kaunas Bernardine convent, 1851 , KAKA, file 142, pp. $845^{-847 v}$; Inventory of the Kaunas Bernardine convent, 26 August 1861, LVIA, col. 1671-4-2, pp. 21-26.

${ }^{8} \mathrm{~A}$ particularly important file is kept at the LVIA in col. 1671-4-71. It contains documents of the Diocese of Samogitia (Telšiai) dating from the second half of the 19th century relating to the activities of convents. There are notes of the Kaunas Bernardine nuns addressed to the Bishop of Samogitia (Telšiai), the bishop's Chancellery and convent visitators, and their responses to the convent. Sometimes the bishop would simply write his response on the reverse of the letter he had received.
} 
Wołonczewski, ${ }^{9}$ and others. Until now, historians have devoted more attention to the architecture and artistic heritage of the former Holy Trinity Bernardine Convent in Kaunas (currently the Kaunas Seminary), ${ }^{10}$ whereas the nuns and their daily life are still shrouded in mystery, with only brief mentions of a general nature appearing in works discussing the life of nuns and friars of the Bernardine Order in Poland and Lithuania. ${ }^{11}$

\section{Problems with mother superiors and the composition of nuns at the convent}

As in the times of the Grand Duchy of Lithuania, so too in the early 19th century, there were usually several dozen sisters living in the Bernardine convent. ${ }^{12}$ Care was taken not to accept too many nuns into the community, so that there would be enough resources for their maintenance. However, after 1842, the Bernardine convent in Kaunas had to have no less than 19 nuns, with the vacancies usually being filled by elderly sisters from other convents, regardless of the different customs of each convent.

The most important figure in the convent was the mother superior, elected for a term of three years. She usually had the last word on various issues at the convent. The same person could not be elected as mother superior for two terms in a row. She had to be older than 40 years of age, and had to have made her solemn

${ }^{9}$ M. Valančius, Namu užrašai, ed. A. Prašmantaitè (Vilnius, 2003); M. Valančius, Pastabos pačiam sau, ed. L.U. Urbaitė (Vilnius, 1996).

${ }^{10}$ Kauno architektūra, ed. A. Jankevičienè (Vilnius, 1991); Oksas, 'Buvusio bernardinių vienuolyno ansamblio', pp. 203-243; R. Janonienė, 'Kauno buvęs bernardinių vienuolynas ir Švč. Trejybės bažnyčia', in: Lietuvos vienuolynai. Vadovas (Vilnius, 1998), pp. 88-92.

${ }^{11}$ S.K. Kantak, Bernardyni polscy, t. 1: 1453-1572; t. 2: 1573-1795-1932 (Lwów, 1933); W. Murawiec, Kowno, Klasztory bernardyńskie w Polsce $w$ jej granicach historycznych. Dzieło zbiorowe pod redakcją ks. H.E. Wyczawskiego (Kalwaria Zebrzydowska, 1985), pp. 513-517; M. Borkowska, Zakony żeńskie w Polsce w epoce nowożytnej (Lublin, 2010).

${ }^{12}$ In 1804 there were 15 sisters living at the Kaunas Bernardine convent, 17 in 1818 , and 18 in 1820 . Visitation of the Kaunas Bernardine convent, 7 June 1804, KAKA, col. 142, p. 853v; Visitation of the Kaunas Bernardine convent, 1818, LVIA, col. 694-1-4014, pp. 672v-673; Visitation of the Kaunas Bernardine convent, 31 July 1820, LVIA, col. 691-1-3669, pp. 354v-356. 
vows at least eight years previously. ${ }^{13}$ Thirteen nuns with voting rights took part in elections held at the Bernardine convent in Kaunas on 21 January 1842 . Sisters who had taken their vows less than two years previously were not allowed to vote. According to the tradition, elections were overseen by four Kaunas Bernardine friars: the abbot, the Bernardine nuns' confessor, and two others. The 44-year-old Klara Korzeniewska was elected as the new mother superior almost unanimously, ${ }^{14}$ after a failed attempt at the position in $1839 .{ }^{15}$ Even though reports from the other two elections have not survived, it is believed that between 1845 and 1851, the Kaunas Bernardine nuns were under the guidance of Elżbieta Kozłowska and Duklana Siemaszkówna.

When the Kaunas Bernardine friary was closed down in $185^{\circ}$, elections held on 10 January $185^{1}$ at the Kaunas Bernardine convent were supervised by the Kaunas dean and Kèdainiai parish priest Jerzy Olszewski, the Kaunas gymnasium chaplain Antoni Rajunec, and two former Kaunas Bernardine friars, the Bernardine sisters' chaplain and preacher Dominik Jagiełowicz, and the preacher Chryzugan Losicki. The role of the friars from the closed Bernardine friary in this election was secondary. Four sisters were put forward to be mother superior: Teodora Lewgowdówna and Aniela Juszkiewiczówna received one vote each, Klara Korzeniewska received two votes, while Róża Grużewska received 14 votes, and was confirmed as the new mother superior. ${ }^{16}$

A visitation conducted in $185^{1}$ presented a complete list of the Bernardine nuns: there were 19 professed nuns (those who had taken their solemn vows) and one novice. ${ }^{17}$ Bishop Wołonczewski

\footnotetext{
${ }^{13}$ Regulamen zakonny, pp. 71-74. The term 'profession' refers to the solemn vows professed by nuns and monks.

${ }^{14}$ Kaunas Bernardine convent election results, 21 January 1842, LVIA, col. 1671-4-361, p. 51.

${ }^{15}$ M. Borkowska, Leksykon zakonnic polskich epoki przedrozbiorowej, t. 3: Wielkie Księstwo Litewskie i Ziemie Ruskie Korony Polskiej (Warszawa, 20o8), p. 56.

${ }^{16}$ Report by Olszewski, 1851, LVIA, col. 1671-4-71, pp. 55-56.

${ }^{17}$ Kaunas Bernardine convent visitation, 1851 , KAKA, file 142, p. $847 \mathrm{v}$. The list includes: 'Róża Grużewska przełożona, Klara Korzeniewska b. przełożona, Elżbieta Kozłowska b. przełożona, Franciszka Andrijewska, Justyna Januszkiewiczówna, Maryaniella Stefanowiczówna, Krystyna Malinowska, Izabella Kuleszewska, Teresa Lenkiewiczówna, Michalina Szadziewiczówna, Agnieszka Puksztówna, Kunigunda
} 
had recommended, or more accurately insisted, that the 23-yearold dowry-less novice Justyna Czapowska join the convent. The Bernardine sisters agreed to accept her, even though the convent was already 'fully occupied' at the time (19 nuns), ${ }^{18}$ which had a detrimental effect on the community's material situation. Czapows$\mathrm{ka}$ is mentioned in December $185^{2}$ as an aspirant who had gone to her mother to improve her health, ${ }^{19}$ and probably never returned to the convent. It appears that the bishop's support was not enough, she did not find her place in the community, or perhaps she was in poor health, or lacked the commitment to lead a devout life.

In 1852, the Bernardine nun Kazimiera Dowkont from Užupis in Vilnius, in her letter to Bishop Wołonczewski, expressed her wish to transfer to the Kaunas Bernardine convent. After spending several years in the Užupis convent, she felt unwell and wanted to live in Kaunas closer to her relatives. ${ }^{20}$ Bishop Wołonczewski wrote to Grużewska, the Kaunas Bernardine mother superior, asking if there were free places at the Kaunas convent. Grużewska replied that the Kaunas convent was already full, and that it would not be beneficial for Dowkont to move in; however, she said the bishop's decision would be final. A letter to the Užupis Bernardine nuns bore the response of the Chancellery of the Bishop of Samogitia (Telšiai) that there were no vacancies at the Kaunas convent. ${ }^{21}$

On 5 July 1853, Grużewska wrote to Bishop Wołonczewski that after a long illness, the 80-year-old Basilian nun Krystyna Malinowska had passed away at the Kaunas Bernardine convent. She had no relatives. The sisters secretly buried her in the cellar of the church, and asked the bishop to allow them to accept a young nun (also in secret) in order to renew and revive the convent's

Ocicszkówna, Teodora Lewgowdówna, Antonina Kobylińska, Delfina Trzeciakówna, Eustachia Juszkiewiczówna, Kazimira Ibiańska, Anna Bonakówna, Aniela Juszkiewiczówna, Justyna Czapowska probantka'.

${ }^{18}$ Letter from the Chancellery of the Bishop of Samogitia (Telšiai), 20 January 1851, LVIA, col. 1671-4-71, p. 58; letter from Grużewska, 31 January 1851, LVIA, col. 1671-4-71, p. 64 .

${ }^{19}$ Letter from Grużewska, 14 December 1852, ibid., p. 213.

${ }^{20}$ Letter from Dowkont, 28 February 1852 , ibid., p. 170.

${ }^{21}$ Letter from Grużewska, o8 April 1852, ibid., p. 171. 
composition. ${ }^{22}$ The bishop rejected this proposal on all counts. He ordered that the convent visitator be informed of Malinowska's passing as soon as possible, and to add a nun from the same rule from a convent in another diocese. He also reminded the nuns of the previous year's request by the Vilnius Bernardine nun Dowkont to be transferred to the Kaunas convent: he claimed that he would have agreed to the transfer at the time, only the answer from the mother superior that the Kaunas convent was fully occupied had prevented him. ${ }^{23}$

These cases illustrate the efforts the Kaunas Bernardine nuns made to avoid having older nuns from other convents transferred to their institution, and their aim to see the ageing Kaunas community revitalised by the admittance of younger sisters. They also testify to the nuns' obedience to the bishop, for without his approval, they did not dare to take any independent action. It could be that this case encouraged the spread of the story among Lithuania's nuns about the secret admission of new members after the deaths of older sisters, thereby creating the image of solemn nuns. These legends are still alive among today's Benedictines and the Sisters of St Catherine in Kaunas. ${ }^{24}$ But it is likely that in reality no nuns from a single convent managed to achieve this. The case of the Kaunas Bernardine nuns shows that these ideas were alive in the 19th century, and that the legend is based on actual facts.

On 9 Janaury 1854, elections for a new mother superior were held, under the supervision of the Kaunas Augustinian prior Raymond Pietkiewicz, the Bernardine nuns' confessor Daniel Jawgieł, and the chaplain Stephan Lukasziewicz. Going against the Bernardine nuns' constitution, but probably on account of her merits, it was suggested to appoint Grużewska to the post for a second consecutive term; alas, she declined. Imagine the

${ }^{22}$ Letter from Grużewska, 5 July 1853, ibid., p. 248.

${ }^{23}$ Letter from Bishop Wołonczewski, ibid., p. 249.

${ }^{24}$ For more, see: Laukaitytė, Lietuvos vienuolijos, p. 35; V. Kamuntavičienė, Kauno benediktiniu vienuolyno tyrimai, t. 1, Kauno benediktinių vienuolyno istorija (Kaunas, 2016), p. 220. It should be said that so far, researchers have not found additional written sources about attempts to admit nuns in secret into Lithuanian convents during the period under research. 
ceremony: Grużewska was asked three times, and she declined all three times. Regardless of her stance, one nun still voted for her. Eustachia Juszkiewiczówna received another vote. In the end, Klara Korzeniewska was elected as mother superior, with 15 votes. ${ }^{25}$

We have no information whether any nun from the Kaunas Bernardine convent took her solemn vows after 1848 . While some were admitted to the novitiate, the community eventually declined. In 1857, Korzeniewska, who was the mother superior at the time, was blamed for the situation: she was accused of admitting women to the convent who did not have a vocation, and without involving the community of nuns in the discussions. ${ }^{26}$ The composition of nuns at the convent was filled by sisters transferred from other institutions in the Russian Empire. For example, Franciszka Andrzeiewska ${ }^{27}$ arrived from the Grodno Bernardine convent, while Anna Korsakówna arrived from the Minsk Bernardine convent. ${ }^{28}$

Grużewska resumed the position of mother superior in $1857 .^{29}$ Three years later, in 186o, she was replaced by Elżbieta Kozłowska. We do not have the protocols from these elections, so no further details are available..$^{30}$ Grużewska was once again elected mother superior in the new elections held on 8 August $1863^{31}$ and she remained the convent's head until its closure in 1864 . Thus,

${ }^{25}$ The results of elections held at the Kaunas Bernardine convent, 9 January 1854, LVIA, col. 1671-4-71, l. 269; letter from Bishop Wołonczewski confirming the election results, 6 February 1854, ibid., p. 271.

${ }^{26}$ Letter from [Grużewska], 12 June 1857, ibid., pp. 311-312.

${ }^{27}$ She was mentioned at the Grodno convent in the 1810 s, see: D. Piramidowicz, Kościół p. w. Narodzenia Matki Boskiej, śś. Antoniego i Kazimierza oraz klasztor bernardynek, Materiaty do dziejów sztuki sakralnej na ziemiach wschodnich dawnej Rzeczypospolitej, ed. J.K. Ostrowski, cz. IV, Kościoty i klasztory rzymskokatolickie dawnego województwa trockiego, ed. M. Kałamajska-Saeed, t. 3, Kościoty Grodna (Kraków, 2016), p. 139. In 1839, she was already living in Kaunas, and was considered for appointment as the discrete, but as she had arrived from another convent, she was thought to be unsuitable for this position. See: Provincial Acts of Lithuania, Archiwum Prowincji Bernardynów w Krakowie (AProwBern), L 3, p. 71.

${ }^{28}$ She moved to Kaunas before 1854 , see: Election results, 9 January 1854 , LVIA, col. 1671-4-71, p. 269 .

${ }^{29}$ Letter from Jawgieł, 18 August 1857, ibid., p. 314.

${ }^{30}$ Letter from Giedroyć, 18 July 186o, ibid., p. 420.

${ }^{31}$ Letter from Kozłowska, 7 August 1863, ibid., p. 487. 
Grużewska occupied the post of mother superior three times in the period from 1850 to 1864 .

In summary, the process of forming the right group of nuns at the Kaunas Bernardine convent did not always go smoothly. The Bishop of Samogitia (Telšiai), the mother superior and the nuns all had their own opinions regarding the formation of the community; however, in reality, the community of nuns would basically be filled with older sisters transferred from other convents, and had no actual influence on its formation.

\section{Problems with the chaplains to the Bernardine nuns}

Chaplains are a critical element in every community of nuns. In their role as confessors, they contribute to the formation of the nuns, they are the first to notice the problems in a convent, and they suggest how they can be corrected. As preachers, chaplains are also very important figures in the education of the nuns and in forming their spirituality. Administering the sacraments, holding Mass and conducting other religious services ensure that the community's customs and traditions are upheld.

Ever since the founding of the Bernardine Order of nuns in Kaunas, their chaplains had always been Kaunas Bernardine friars. However, in $185^{\circ}$ the friary was closed, and the Bernardine sisters were put under the jurisdiction of the Bishop of Samogitia (Telšiai), Maciej Wołonczewski. Two Bernardine friars, Jagiełowicz and Losicki, were allowed to continue living in a small house near the Bernardine convent in Kaunas, where they served as chaplains. This meant that the Bernardine friars could remain near their friary. Grużewska, the mother superior, passed on the gratitude of the friars to the bishop for letting them stay in Kaunas, and the chaplains declared that they would continue to work devotedly for the benefit of the whole city. ${ }^{32}$ However, their situation in Kaunas was not very certain, there was always the threat of transfer, they lost the income they had once had, and they had to make do with what the Bernardine nuns could give them. These problems faced

${ }^{32}$ Letter from Grużewska, 22 September 1851 and the bishop's response, ibid., pp. 103,107 . 
by the chaplains unavoidably influenced the life in the community of Bernardine nuns as well.

When the Kaunas Bernardine friary was still open and offered spiritual services to the nuns, the latter would pay them a fee of 66 silver roubles, which would be given as an offering at the Church of the Holy Trinity during Mass said on holy days of obligation for benefactors. Now that only two Bernardine friars remained living in the small house, it was the nuns who provided for them (food, laundry and firewood) and paid their allowance. However, Grużewska ventured to ask the bishop whether the Bernardine nuns still had to pay the brothers the 66 roubles, and perhaps just providing them with necessities would suffice. Wołonczewski recommended that they continue paying the allowance, as food, laundry and firewood were the accepted and already rather meagre payment for the religious services of two Bernardine friars. ${ }^{33}$ This was how the Bernardine nuns' expenses for their chaplains increased after 185 o.

It was not long before Wołonczewski received a letter from the concerned Bernardine nuns, written on 10 November 1851 by the mother superior, Grużewska, and her assistants Korzeniewska and Kozłowska, that Losicki was being transferred out of Kaunas. The Bernardine nuns were disappointed that such a fine priest as Losicki, who was exemplary in performing services to both the Bernardine nuns and all the faithful in Kaunas, was being recalled from his position as chaplain. They asked if there was any chance of changing this decision. ${ }^{34}$ However, Wołonczewski told the nuns to calm down, to accept the decision obediently, and to trust the bishop, who would not send them a worse chaplain than the previous one. ${ }^{35}$ In this way, Losicki was replaced by Stephan Lukasziewicz.

The other remaining Bernardine chaplain, Jagiełowicz, was not pleased with his situation at the time. He complained to the bishop that, according to the $185^{2}$ Church calendar, he had not been allocated to any monastery or convent, and feared being dismissed

\footnotetext{
${ }^{33}$ Ibid.

${ }^{34}$ Letter from Grużewska, 10 November 1851, ibid., p. 113.

${ }^{35}$ Letter from Bishop Wołonczewski, 17 November 1851, ibid., p. 114.
} 
altogether, as had happened to Losicki, adding that he wished to continue serving the Bernardine nuns. ${ }^{36} \mathrm{He}$ also complained that his provision was not enough: he only received food and shelter, but he also needed money for clothes, shoes, etc. The chaplain reminded the monastery and convent visitator Giedroyć that the Bernardine nuns were receiving 40 roubles from the Treasury to maintain a chaplain. ${ }^{37}$ In her response to these reproaches, on 17 February 1852, Grużewska stated that, as in the past, the sisters would pay the chaplains Jagiełowicz and Lukasziewicz 66 roubles and 5 o kopeks, and, as usual, the convent would provide them with food, firewood, light and laundry services, and would offer them coffee and tea. ${ }^{38}$ Unfortunately, after falling ill with cholera, Jagiełowicz died on 10 September 1853. The Bernardine nuns stated that they had summoned a doctor, but there were complications, his fever had worsened, and despite the doctor's efforts, the chaplain had passed away. ${ }^{39}$ It just so happened that that same autumn, Sylwain Gimbut, a friar from the Bernardine friary in Minsk, was passing through Kaunas, and having learned of Jagiełowicz' death, said he would like to continue his work, so that he could live closer to his relatives in Samogitia. Even though the Bishop of Samogitia (Telšiai) did not refuse this request, ${ }^{40}$ Gimbut did not stay in Kaunas very long. By January 1854, the Bernardine nuns' confessor was Daniel Jawgiel.

The material problems faced by the chaplains to the Bernardine nuns remained unresolved. It seems that the nuns themselves did not have enough resources to provide for their maintenance. In 1855, the chaplain Lukasziewicz complained to the bishop about his unsatisfactory situation. He stated that he had served the nuns for five years, during which time he had fallen ill and owed the doctor 45 roubles, for which he would have to hold Mass. In that

\footnotetext{
${ }^{36}$ Letter from Jagiełlowicz, January 1852, ibid., p. 187 .

${ }^{37}$ Letter from Giedroyć, 26 January 1852, ibid., p. 133.

${ }^{38}$ Letter from Grużewska, 17 February 1852 , ibid., p. 16 o.

${ }^{39}$ Letter from Grużewska, 17 September 1853 , ibid., p. 25 o.

${ }^{40}$ Letter from Grużewska, 1 October 1853 and the bishop's response, ibid., pp. 257,
} 259 . 
time, he had worn out his clothes and shoes, but did not have enough money to buy replacements, and nor could he pay the man who brought him water and firewood and took his laundry to the washerwoman. In return for those services, he would share the lunch he received at the convent with the man, and would offer him a glass of tea. The chaplain noted that a new confessor, Jawgieł, had recently arrived at the convent, who was dressed in new clothes and had two rooms at his disposal, one of which he let out to a carpenter, a carver of Christ's Suffering, who would work for him as payment for the room. Lukasziewicz complained that he had only one room, and could not imagine occupying two, he did not even own a habit, as was outlined in the monastery rules. Probably the final test of the chaplain's patience was the flood in Kaunas, during which the chaplain's small house and all its contents were damaged. Under these conditions, and still feeling in debt, Lukasziewicz asked Bishop Wołonczewski to appoint him to another monastery; ${ }^{41}$ the bishop granted this request.

By 1855 , the Bernardine sisters were left with one chaplain, Jawgiel. We can presume that the situation with the chaplain settled down somewhat, as the nuns were able to provide for one priest. Jawgieł did not complain about life in Kaunas, he served as chaplain to the Bernardine nuns until the convent's closure in 1864, after which he moved to Švèkšna, where he was appointed as an altarist. ${ }^{42}$ On the other hand, when the Bernardine nuns were under the jurisdiction of the provincial of the Bernardine Order in Lithuania, a rotation of confessors at least once every three years was ensured. Jawgieł served the nuns for ten years. This is an indication of the change in customs. The Bishop of Samogitia (Telšiai), under whose jurisdiction the Bernardine sisters were placed, paid little attention to the rotation of chaplains. This might also have been difficult due to the Russian government's policy, because every transfer of a member of the clergy had to be approved by the authorities. We can only guess how much this

${ }^{41}$ Letter from Lukasziewicz, 2 April 1855, ibid., pp. 293-294.

${ }^{42}$ Valančius, Namu užrašai, pp. 665-667; Valančius, Pastabos pačiam sau, p. 142. 
would have influenced life in the community, and the extent to which it allowed other problems to develop.

\section{Problems living in a closed community}

The constitution of nuns of the Bernardine Order mentions the importance of community life, and ways that it can be ensured. In practice, various problems would arise that the sisters would usually resolve within their own community, so it is difficult to find information about what they could have been. However, when a solution could not be found, the sisters sometimes had occasion to refer the situation to their ecclesiastical superiors.

In around 185 , one Kaunas Bernardine nun (her name has not survived in sources, but Wołonczewski must have known it) complained to the Bishop of Samogitia (Telšiai) that she had to share a cell with another nun who suffered from the plica polonica ('Polish plait'), which she treated with various herbs and ointments that emitted an unpleasant odour. The nun desperately wanted a separate cell, especially as it was even indicated in the constitution that nuns should be given their own cells. However, probably on account of the increased number of sisters and the worsening material situation, this had become difficult to guarantee. While the other nuns felt sorry for her, the mother superior had allegedly retorted 'It won't kill you,' and left her in the same cell with the plica sufferer. This attitude taken by the mother superior was very condescending. The nun in question resorted to making a complaint to the bishop, asking for his help to secure a separate heated cell, as the 15 roubles that were officially allocated for the maintenance of one nun were nowhere near enough to buy firewood for heating as well. She claimed she was an orphan, with no relatives who could support her financially. And even if she did have some money, she said the mother superior would not allow the servants to leave the convent to buy firewood. ${ }^{43}$

Thus, poor material conditions, illness and difficult interpersonal relations were all evident at the Bernardine convent in Kaunas. It could also be mentioned that the plica was rife among other nuns.

\footnotetext{
${ }^{43}$ Letter from a nun, LVIA, col. 1671-4-71, p. 58a.
} 
In 1851, Tomasz Budrecki, the chaplain to the Kražiai Benedictine nuns, wrote to Wołonczewski asking him to allow the Kražiai Benedictine nun Melania Siawciłówna to seek medical attention for the plica in Šiluva, and confess her sins to a priest of her choice. ${ }^{44}$ If we return to the Kaunas Bernardine nun's letter, we notice that it contains evidence of a specific attitude towards poverty and communal property in Bernardine convents in the Grand Duchy of Lithuania. According to the constitution, Bernardine nuns were allowed a personal income; however, it had to be left with the mother superior, and used only with her permission. ${ }^{45}$ So even after becoming a nun, a Bernardine nun had the possibility to live more comfortably than the other sisters if she had wealthy relatives or personal sponsors. This would obviously have added to discord in the community.

The circumstances at the convent took a turn for the worse under Mother Superior Korzeniewska. On 12 June 1857, a Kaunas Bernardine nun (the letter was signed, but the surname was later cut out) wrote to Wołonczewski about the difficult situation in the community. ${ }^{46}$ From the content of the letter, it might be guessed that the author was Grużewska, the former mother superior. She was unsettled by the fact that the nuns' cells in the convent were 'full' of secular members of the public living there, relatives, friends and the like, all walking around the convent freely, with all sorts of gaiety going on. There were only a few nuns who ate together, each one had their own separate table (food) and ate separately. This was a violation of a key principle of the constitution, which forbade Bernardine nuns to eat in their own cells; they all had to honour their vows of communal living and poverty, and eat only in the refectory, while listening to readings. Not even leftovers from the dining table could be taken back to their cells. ${ }^{47}$

If that was not enough, according to Grużewska, the condition of the buildings of the Kaunas Bernardine convent was so bad that buckets had to be put everywhere when it rained, so that water

\footnotetext{
${ }^{44}$ Letter from Budrecki, 16 September 1851, ibid., p. 100.

${ }^{45}$ Regulamen zakonny, pp. 64-67.

${ }^{46}$ Letter [from Grużewska], 12 June 1857, LVIA, col. 1671-4-71, pp. 311-312.

${ }^{47}$ Regulamen zakonny, pp. 47-49.
} 
would not run into the cells and other rooms. A similar situation was noticed in the church. The nun was concerned that living in such damp conditions was sure to be bad for the health. This was also another violation of the constitution, which demanded that the church and convent be looked after and maintained, and regularly renovated.

Another malady she noticed was in the selection of novices. In the opinion of the letter's author, women who did not really have a calling were being accepted into the convent, leading to two novitiates running away just before they were due to profess. The problem was that decisions for the selection of candidates were made only by the mother superior and the vicaress, leaving the other nuns out. Novices would live together in one room: this was an unsatisfactory practice, as in reality, two nuns could not even live in one cell, unless in exceptional cases. The novices did not follow the rules on proper demeanour and quietness, and outsiders could be seen walking around. One novitiate room had been set aside for dewotki, ${ }^{48}$ whose carelessness had almost burned the convent down. According to Grużewska, it was actually the convent's mother superior and vicaress who had driven away the second chaplain, Lukasziewicz.

The author of the letter stated that the mother superior hated her because she had not voted for her in the elections (which, according to the author, did not take place honestly), and therefore did not let her become involved in any of the convent's affairs, did not let her into the kitchen, and locked the convent garden, from where she could not pick any fruit. Grużewska asked the bishop to have the laity and the dewotki leave the convent, and to restore order.

While we do not know how Bishop Wołonczewski reacted to this letter, it did not take long for him to respond. Korzeniewska's three-year term as mother superior had just ended, and on 18 August 1857 Grużewska is mentioned as the newly elected mother superior, so she had another chance to take the helm and

\footnotetext{
${ }^{48}$ Dewotki was a term for devout women who took vows of chastity and led a life of prayer.
} 
to amend the situation that had developed. Jawgieł, the Kaunas Bernardine nuns' confessor, wrote on that day asking the bishop to allow the newly elected mother superior and her assistants to go and inspect the convent's folwark. ${ }^{49}$ They must have wanted to find out the situation on the farm for themselves.

On 21 August 1857, Bishop Wołonczewski wrote to Grużewska saying that the convent buildings had fallen into disrepair under the previous mother superior, that water was leaking through the roof, the nuns ate in their cells, the refectory table was devoid of diners, and that laypeople were living in nuns' cells, where they kept cousins, friends and maids. Therefore, he gave strict orders to: (1) repair the convent, especially the roofs; (2) for all the nuns to eat meals in the refectory while readings were read; (3) not to admit lay people in without special permission, and to adhere strictly to the clauses and regula. ${ }^{50}$ This instruction from the bishop basically repeated what had been written in Grużewska's letter, only now it did not sound like a complaint made by a nun, but like orders handed down from a senior member of the hierarchy, the bishop. Wołonczewski himself wrote in his memoirs that the Kaunas Bernardine nuns were living in their own cells, with their own separate kitchens and meals, and kept maids and residents. Some did not even live in the convent. 'This was an obvious abuse and ignorance of the statutes of St Francis, but living so far away, I was not aware of the situation..$^{5^{1}}$ Grużewska certainly opened his eyes.

Even though, according to the constitution, the Bernardine nuns could not leave the convent for any reason, except in the event of fire or flood, in reality, with the bishop's permission, the mother superior and an assistant could leave the convent from time to time to attend to the convent's economic (farm-related) matters. For example, Grużewska, as mother superior, wrote to Bishop Wołonczewski in $185^{2}$ informing him that her permit to

${ }^{49}$ Letter from Jawgieł, 18 August 1857, LVIA, col. 1671-4-71, p. 314.

${ }^{50}$ Letter from Bishop Wołonczewski, 31 August 1857, ibid., p. 316.

${ }^{51}$ Byto to zaiste nadużycie i odstapienie od ustawy św. Franciszka, o czem jednak, daleko mieszkajacc, nie wiedziatem. Valančius, Namų užrašai, pp. 666-667; Valančius, Pastabos pačiam sau, p. 142. 
go to the Virbaliūnai folwark which belonged to the convent had expired, and asked to be issued with a new one. ${ }^{52}$ In the 185 os, the Kaunas Bernardine nuns would often spend the summer with their relatives or go to sanatoriums (Stakliškès was a popular destination) to improve their health. These breaks would last for one to three months, and usually equated to a summer rest. They could enjoy more nutritious food and breathe fresh country air. The bishop would usually satisfy all such requests, and would allow two to four nuns to leave the high walls of the Kaunas Bernardine convent for a few months, so that they could treat their rheumatism, chest illnesses, dropsy, heart palpitations, and liver and head ailments. ${ }^{53}$ However, in 1857 the confessor did not allow Eustachia Juszkiewiczówna to leave, whereupon she complained to the bishop, saying that the first time she had left the convent was only in 1856 , at the age of 70 , and that the trip to her birthplace had greatly helped her improve her health. ${ }^{54}$ Who knows, perhaps the negative answer was partly due to the tension in the convent at the time. In $186 \mathrm{o}^{55}$ and 1861, Grużewska also spent three months in the countryside resting. The priest V. Grużewski, who lived in the Daumantiškès manor, in the parish of Pabaisk in the Vilkmerge district, was her nephew. The River Šventoji flowed nearby, so it was possible to bathe in its waters. ${ }^{5}$

The information available shows that Bernardine nuns who had taken their solemn vows maintained a connection with their relatives. If they could not invite them to visit and stay at the convent, then they would try to go to their relatives in the countryside to rest in the summer, thereby uniquely assisting in

${ }^{52}$ Letter from Grużewska, 19 August 1852, LVIA, col. 1671-4-71, p. 203.

${ }^{53}$ Letter from Grużewska, 3 July 1852, and the bishop's response, LVIA, col. 16714-71, pp. 196-197; letter from Grużewska, 9 May 1853, and the bishop's response, ibid., pp. 231-232; letter from Korzeniewska, 29 April 1854, and the bishop's response, 8 May 1854, ibid., pp. 277-278; letter from Korzeniewska, 27 April 1856, ibid., pp. 296-297, 299-30o; letter from Korzeniewska, 3 o May 1856, ibid., p. 301; letter from Grużewska, 16 April 186o, ibid., pp. 398, 401-402.

${ }^{54}$ Letter from Juszkiewiczówna, 6 June 1857 , ibid., p. 310.

${ }^{55}$ Letter from Giedroyć, 18 July 186o, ibid., p. 420.

${ }^{56}$ Letter from Giedroyć and the bishop's comments, 30 April 1861, 2 May 1861, ibid., p. 451. 
solving the convent's material problems. It was mostly just nuns who were actually unwell who were allowed to leave. This implies that the Kaunas Bernardine convent was unable to provide them with proper rest and care. This tradition of 'restoring one's health' on such breaks existed in other convents at the time. The main problems that plagued the Kaunas Bernardine nuns at this stage were material concerns and the lack of a proper community life.

\section{The closure of the convent and the fate of the Bernardine nuns}

After the uprising of 1863 , the Imperial Russian government decided to find pretexts to close as many Catholic monasteries and convents as possible. The Kaunas Bernardine nuns came in this unlucky category. Even though initially it was still being deliberated which should be closed down, the Benedictine convent or the Bernardine convent in Kaunas, ${ }^{57}$ the decision was soon made, and the Bernardines had to go. This decision might have been related to the location of the Bernardine convent in the city.

The process of closure began in June 1864, and went on for about half a year. On 18 June 1864, already quite concerned, Grużewska wrote in Russian (after the uprising of 1863 , it was not allowed to communicate officially in Polish) to Bishop Wołonczewski, complaining that members of the public were walking around the convent, and government officials were saying that the convent was due to close. Grużewska stated that the convent had been there for over 200 years, it had adhered to all religious and civil orders, and asked that it might continue to function..$^{8}$

In fact, the Imperial authorities planned to transfer the seminary and curia of the Bishop of Samogitia (Telšiai) from Varniai to Kaunas, but they needed to find suitable premises. Some options were the buildings of the already closed Kaunas Bernardine and Discalced Carmelite friaries, and the still-functioning Bernardine convent or the Augustinian monastery. In order to keep

${ }^{57}$ Letter from the Chancellery of the Kaunas governor, 3 July 1864, KAKA, file 16o, pp. $2-3$.

${ }^{58}$ Letter from Grużewska, 18 June 1864, LVIA, col. 1671-4-71, p. 495. 
as many monasteries and convents open in Kaunas as possible, Wołonczewski believed that the seminary could operate from the former Discalced Carmelite friary which had been converted into a military hospital, while the diocesan curia could move into the Augustinian monastery along with the monks, so no additional monasteries or convents would have to be closed. However, the Imperial authorities had their own plans.

Bishop Wołonczewski visited the Kaunas Bernardine convent on 27 July 1864, with the governor-general, Mikhail Muravyov. On inspecting the buildings, he was forced to agree to have the Samogitian (Telšiai) seminary moved to the premises of the Kaunas Bernardine convent, but he hoped that the Bernardine nuns could be moved to Varniai, where they could occupy the seminary buildings. In a way, the buildings would simply change hands. However, this exchange was not to happen. The decision was made to completely abolish the Bernardine convent, and hand over its premises to the seminary (which also took control of the buildings of the Bernardine friary and St George's Church), while the Church of the Holy Trinity of the Bernardine nuns was to be converted to a parish church. The existing Kaunas parish Church of St Peter and Paul, which had been part of the Augustinian monastery, would become the cathedral of the Diocese of Samogitia (Telšiai). ${ }^{59}$

Wołonczewski described Grużewska's reaction to the bishop's visit: 'Mother Superior Róża Grużewska bowed and scraped, the poor thing, and prayed as much as she could for their nest not be taken away; but in vain, for it is considered necessary to take away the convent. ${ }^{160}$ As the note of 18 August 1864 announced, the

${ }^{59}$ V. Merkys, Motiejus Valančius. Tarp katalikiškojo universalizmo ir tautiškumo (Vilnius, 1999), pp. 528-529, 6oo-6o1.

${ }^{60}$ Przetożona Róża Grużewska ktaniata się, tupata biedna i prosita wiele mogta, ażeby nie zabierano ich gniazda. Lecz daremnie, zabór bowiem klasztoru policzono za niezbędnie potrzebny. Valančius, Namų užrašai, pp. 664-665; Valančius, Pastabos pačiam sau, p. 141; Merkys, Motiejus Valančius, p. 6o1. Wołonczewski recorded this visit as having taken place on 9 December; however, he must have made a mistake, because at that time the matter of the convent's hand-over had already been resolved, and the Bernardine nuns had been relocated to other convents. This mistake by Wołonczewski has confused historians for quite some time. See also: A. Gric- 
Kaunas Bernardine nuns were allowed to sell some of the moveable property that belonged to them. ${ }^{6}$ The immoveable property had to be given to the future seminary, along with the Virbaliūnai folwark.

Bishop Wołonczewski now had the task of relocating the 21 Bernardine nuns who lived at the Kaunas convent to other still-functioning convents. A preliminary list was drafted on 16 August 1864. Ten nuns were to be moved to the Kaunas Benedictine convent, four to the Krakès convent of the Sisters of St Catherine, and seven to the Kražiai Benedictine convent. ${ }^{62}$ In November 1864, the possibility of moving some of the Kaunas Bernardine nuns to the Bernardine convent of St Michael in Vilnius was also considered, as the convents in Kaunas and Kražiai were already quite full. ${ }^{63}$ But this idea was dismissed. Official documents regarding the transfer were completed on 1 December. The Bernardine nuns who arrived in the Benedictine convent in Kaunas received five roubles, those going to Krakès received 25 roubles, and those going to Kražiai received 30 roubles each. The money was to cover travel expenses and the costs associated with settling in.

The nuns who moved to the Benedictine convent in Kaunas were the mother superior Roża Grużewska, Ludwika Czaplińska, Klara Korzeniewska, Elżbieta Kozłowska, Duklana Siemaszkówna, Izabella Kuleszewska, Aleksandra Kopciówna, Eustachia Juszkiewiczówna, Dominyka Andrzejkowska, and Kazimiera Ibiańska. Those admitted to Krakès were Franciszka Andrzejewska, Józefa Oleszkiewiczówna, Anna Korsakówna and Tekla Pogorzelska. Marianna Stefanowiczówna, Teodora Lewgowdówna, Julia Przybylska, Delfina Trzeciakówna, Anna Bonekówna, Salomea Siemaszkówna and Kunegunda Ociszkówna went to Kražiai. ${ }^{64}$

kevičius, Kataliku kunigu seminarija Kaune: 150-ies metu istorijos bruožai (Kaunas, 2016), p. 47.

${ }^{61}$ Letter to Bishop Wołonczewski, 18 August 1864, LVIA, col. 1671-4-71, p. 496.

${ }^{62}$ Letter from Bishop Wołonczewski, 16 August 1864, ibid., p. 497.

${ }^{6}$ Letter to Bishop Wołonczewski, 14 November 1864, ibid., p. 498.

${ }^{64}$ List of Kaunas Bernardine nuns transferred to the Kaunas Benedictine convent, 1 December 1864, ibid., p. 503; list of Kaunas Bernardine nuns transferred to the Krakès convent of the Order of St Catherine, 1 December 1864, ibid., p. 504; list of Kaunas Bernardine nuns transferred to the Kražiai Benedictine convent, 1 December 1864, ibid., p. 505. In the list of Kaunas Bernardine nuns, Bishop Wołonczewski 
The Bernardine nuns who ended up in the Benedictine convent tried to maintain their constitution and customs, but they had to obey the orders of the Benedictine abbess. In 1866, Sofia Głębocska, the abbess of the Kaunas Benedictine nuns, asked to keep the two existing priests as chaplains in their convent, especially since another ten Bernardine nuns were also now living in their convent. ${ }^{65}$ The Bernardine sisters formed small, separate communities in the convents in Kražiai and Krakès.

When the seminary moved into the buildings of the former convent of Kaunas Bernardine nuns, and the Church of the Holy Trinity was made into a parish church, the clergy came into contact with the legacy of the Bernardine nuns. More comprehensive research is required to learn about their actions, and how it was adapted for their purposes. However, the discovery of the undecomposed remains of a nun in the cellar of the Church of the Holy Trinity attracted a lot of attention. The Bishop of Samogitia (Telšiai) immediately wrote to the Bernardine sisters now living in the Benedictine convent in Kaunas, asking for more information. On 6 April 1874, Grużewska and Juszkiewiczówna replied that they did not know who had been buried there, and could not check either, complaining that, deemed as being unnecessary to other convents, the convent's archive documents had been burnt (papiery iakie byly $w$ archiwum klasztoru naszego polono iako niepotrzebnych dla cudzych klasztorów). Thus, the Bernardine nuns could not remember whose remains were in the cellar, when the individual had been buried, what family the nun had come from, and how her life was different to others; but they did think that the remains were very old. It was thought that the body was one of the first nuns and founders of the convent, as the dedication and fervour of the first nuns were much more intense than among the later ones; the first were deemed more devout. Later generations of nuns had considered her as being blessed, and dressed her in a nun's habit. The letter conveyed a sense of nostalgia for better times. It could be that, constantly returning to the convent's

missed out Andrzejkowska, Ociszkówna and Stefanowiczówna. See: Valančius, Pastabos pačiam sau, p. 142; Valančius, Namų užrašai, pp. 665-667.

${ }^{65}$ Letter from Glębocka, 17 October 1866, LVIA, col. 1671-4-71, p. 511. 
closure in her mind, Grużewska considered the act as a kind of punishment from God for the violations of the nuns' constitution and their distance from the initial solemn ideals.

Also, jumping at the chance to express their views, the Bernardine nuns complained about their difficult life in the Benedictine convent in Kaunas. They lacked resources to buy habits, underclothes and other supplies. They wore the same habits they had, despite the fact that they were torn and ragged. The outward appearance would suggest that they did not care about their appearance, but in actual fact they simply did not have enough money. They asked the bishop to help the poor Bernardine nuns, so that they could order some material from a Bernardine factory and make themselves the standard dress (z bernardynskiey fabryki $i$ odziać sie jednostaine sukienki). This information shows that the Bernardine sisters did try to distinguish themselves from the Benedictine nuns, and to adhere to the Bernardine rule. ${ }^{66}$ They were listed separately on the list of nuns in the Benedictine convent in Kowno.

Aleksandra Rimsziewicz, the abbess of the Kražiai Benedictine nuns, also complained of a shortage of money after the Bernardine nuns had been transferred to their convent. ${ }^{67}$ As before, the Bernardine sisters living in Kaunas, Kražiai and Krakès tried to visit relatives in the summer and eat wholesome food. ${ }^{68}$ We know of several attempts by the Kaunas Bernardine nuns to try to move to St Michael's Bernardine convent in Vilnius, and understandably so, because the same regula applied there. It is no secret that this convent in Vilnius was one of the wealthiest, so better material provision could also have been one of the reasons for wanting to move there. In 1873, the Bernardine nun Sister Przybylska, who lived in the Kražiai Benedictine convent, expressed her wish to move to the St Michael's community, justifying herself by the fact that she had relatives in Vilnius who could provide her with

\footnotetext{
${ }^{66}$ Letter from Grużewska, 6 April 1874, ibid., p. 596.

${ }^{67}$ Letter from the abbess at the Benedictine covent in Kražiai, 16 March 1871, ibid., p. 576 .

${ }^{68}$ Letters from the Benedictine sisters in Kražiai, ibid., pp. $528,531,561-562$; letters from the Benedictine sisters in Kaunas, LVIA, col. 1671-4-132, pp. 473, 478-479, 482.
} 
material support. The priest from the Kražiai Benedictine convent, Fr T. Budreckis, wrote to Bishop Wołonczewski about this. ${ }^{69}$ In 1884, Jusziewiczówna and Ibiańska, the only two Bernardine sisters who were still alive, announced that they wanted to do the same. ${ }^{70}$ However, St Michael's Convent in Vilnius was closed altogether in 1886, and the three Bernardine nuns who remained there were moved to the Benedictine convent in Vilnius.

The Benedictine convent in Kražiai was closed in 1893. At the time, only one Bernardine nun from Kaunas, Siemaszkówna, was still there. According to a resolution dated 8 May 1893, she was moved to the Benedictine convent in Kaunas..$^{71}$ This meant that throughout her life, she had to change convents three times. Three of the four Bernardine sisters who had moved in with the Sisters of St Catherine in Krakès died in the 19th century; the last one, Sister Pogorzelska, passed away on 19 December $1898 .^{72}$

Only two nuns from the former Bernardine convent in Kaunas survived into the 2oth century, Sister Ibiańska and Sister Siemaszkówna, who came to the Benedictine convent in Kaunas from Kražiai. Ibiańska died on 11 January 1907. Siemaszkówna went to visit St Catherine's Convent in Krakès in 1914, where she died unexpectedly at 1opm on 22 October, aged 86. As is testified by Maciej Kaziłewski, the chaplain at St Catherine's Convent, she was buried in the cemetery of St Catherine's Convent in Krakès on ${ }_{25}$ October. $^{73}$ The nuns did not omit to mark on her tombstone that a Bernardine sister was laid to rest there. This Kaunas Bernardine nun lived in the Benedictine convents in Kražiai and in Kaunas, and died at St Catherine's Convent in Krakès. So ends the history of the Bernardine nuns of Kaunas, which lasted for $5^{\circ}$ years after its closure in 1864 until the passing of the last sister.

${ }^{69}$ Letter from Budrecki, 24 August 1873, LVIA, col. 1671-4-71, pp. 593, 594.

${ }^{70}$ Kamuntavičienè, Kauno benediktiniu vienuolyno, pp. 216-217, 362-363.

${ }^{71}$ Ibid., pp. 218, 365 .

${ }^{72} \mathrm{~V}$. Kamuntavičienè, Krakiu kotryniečiu vienuolynas: nuo dievotu bendruomenès iki Lietuvos kotryniečiu provincijos (Kaunas, 2019), pp. 105, 426.

${ }^{73}$ Report by Kazilewski to the visitator, 26 October 1914, Archive of the Sisters of St Catherine in Kaunas, file 2, p. 25v. 


\section{Conclusions}

In summary, below are the most important points in the lives of the Kaunas Bernardine nuns in the years 1842 to 1864 .

The first problem was material provision. Once they lost their sponsored domains in 1842, the allowance from the Treasury was insufficient, so the nuns would try to secure material support from relatives and other lay people. This led to the formation of separate kitchens for the nuns, leaving the refectory empty, which had a negative impact on community life.

The second problem was the closure of the Bernardine friary in Kaunas in 1850, under whose protection the Bernardine nuns had been placed. Even though two Bernardine friars initially stayed on living close to the former friary, and continued to provide religious services to the Bernardine nuns, they eventually faced a lack of money and impoverishment, and the Bernardine sisters could not provide for them. Understandably, this affected the religious services. By 1855 , only one chaplain, Jawgieł, remained. He ignored or did not want to see the problems plaguing the Bernardine convent, did not search for ways to solve them, and neither did he inform the visitator or bishop about their existence. Once the Bernadine friary was closed down, the Bernardine nuns came under the jurisdiction of the Bishop of Samogitia (Telšiai), Maciej Wołonczewski. He should have made sure the convent was in a satisfactory condition, but since he lived in Varniai, far from Kaunas, he was not able to observe life at the Bernardine convent closely or notice the problems there.

Another problem was the difficult interpersonal relations between the Bernardine nuns, the frequent lack of communality and sisterly love between them, thriving individualism, too much contact with lay people, and violations of the rules of cloistered living and the vows of poverty. All this weakened the community and made it vulnerable. Mother Superior Grużewska went to great lengths to improve the dire situation among the sisters.

Regardless of these problems, the Bernardine way of life had formed among the nuns in line with their traditions and constitution. This became particularly obvious after the convent's 
closure. Having lost their home, the Bernardine nuns never really integrated into the Benedictine communities in Kaunas or Kražiai, or with the Sisters of St Catherine in Krakès. They stood out by their clothing, and most likely their customs as well.

The main reason why the Kaunas community of Bernardine nuns became so weak could have been the actions of the Russian occupying authorities, which created particularly unfavourable conditions for convents. These external reasons led to a number of internal problems in the community. Attempts to improve the situation ranged from changing mother superiors to trying to draw the bishop's attention to the community's problems. Generally speaking, the internal issues they faced were not so great that they would have caused the natural decline of the convent. Alas, the Bernardine convent in Kaunas was finally abolished in 1864, by decree of the Russian authorities.

\section{Author Details}

Vaida Kamuntavičienė is a doctor in humanities (history) and a professor in the Department of History at Vytautas Magnus University. Her academic fields of interest are: the history of the Catholic Church in Lithuania, microhistories. Address: VMU Department of History, 23-404 V. Putvinskio St, Kaunas, Lithuania ORCID: oooo-ooo2-9147-4214

Email: v.kamuntaviciene@gmail.com

\section{Bibliography}

BORKOWSKA, Małgorzata. Leksykon zakonnic polskich epoki przedrozbiorowej, t. 3: Wielkie Księstwo Litewskie i Ziemie Ruskie Korony Polskiej (Warszawa, 2008).

BORKOWSKA, Małgorzata. Zakony żeńskie $w$ Polsce $w$ epoce nowożytnej (Lublin, 2010).

GRICKEVIČIUS, Artūras. Kataliku kunigu seminarija Kaune: 150-ies metu istorijos bruožai (Kaunas, 2016).

JANONIENE, Rūta. Kauno buvęs bernardinių vienuolynas ir Švč. Trejybės bažnyčia, in: Lietuvos vienuolynai. Vadovas (Vilnius, 1998), pp. 88-92.

KAMUNTAVIČIENE, Vaida. Kauno benediktiniu vienuolyno tyrimai, t. 1: Kauno benediktiniu vienuolyno istorija (Kaunas, 2016). 
KAMUNTAVIČIENĖ, Vaida. Krakių kotryniečių vienuolynas: nuo dievotu bendruomenès iki Lietuvos kotryniečiu provincijos (Kaunas, 2019).

KANTAK, Stefan Kamil. Bernardyni polscy, t. 1: 1453-1572; t. 2: 15731795-1932 (Lwów, 1933).

KATILIUS, Algimantas. Moterų vienuolynų tinklas buvusios Lietuvos Didžiosios Kunigaikštystės žemėse XVIII a. pabaigoje - XX a. pradžioje, in: Lietuvos Didžiosios Kunigaikštystès moterų vienuolijos: istorija ir paveldas, sud. A. Vasiliauskienè (Kaunas, 2014), pp. 23-36.

Kauno architektūra, ed. A. Jankevičienè (Vilnius, 1991).

Krikščionybès Lietuvoje istorija, ed. V. Ališauskas (Vilnius, 20o6).

LAUKAITYTE், Regina. Lietuvos vienuolijos. XX amžiaus istorijos bruožai (Vilnius, 1997).

MERKYS, Vytautas. Motiejus Valančius. Tarp katalikiškojo universalizmo ir tautiškumo (Vilnius, 1999).

MURAWIEC, Wiesław. Kowno, in: Klasztory bernardyńskie w Polsce w jej granicach historycznych. Pod redakcją ks. H.E. Wyczawskiego (Kalwaria Zebrzydowska, 1985), pp. 513-517.

OKSAS, Jurgis. Buvusio bernardinių vienuolyno ansamblio Kaune (dab. Tarpdiecezinė kunigu seminarija) istoriniai tyrimai, in: Kauno istorijos metraštis, 1 (Kaunas, 1998), pp. 203-243.

Regulamen zakonny, albo Konstytucye panien zakonnych Prowincyi W. X. Litewskiego, swiętego Kazimierza Zakonu świętego Franciszka, z rożnych statutow generalskich, y prowincyalskich; z wielu także dekretow papieskich generalnie zebrane, potym zupetna wtadza od Kapituty Generalskiey w Hiszpaniey korrygowane, konfirmowane, y do zachowania tymże pannom zakonnym podane (W Supraslu, 1740).

PIRAMIDOWICZ, Dorota. Kościół p. w. Narodzenia Matki Boskiej, śś. Antoniego i Kazimierza oraz klasztor bernardynek, in: Materiaty do dziejów sztuki sakralnej na ziemiach wschodnich dawnej Rzeczypospolitej, ed. Jan K. Ostrowski, cz. IV, Kościoty i klasztory rzymskokatolickie dawnego województwa trockiego, red. M. Kałamajska-Saeed, t. 3, Kościoty Grodna (Kraków, 2016), pp. 133-16o.

VALANČIUS, Motiejus. Namu užrašai, ed. A. Prašmantaitė (Vilnius, 2003).

VALANČIUS, Motiejus. Pastabos pačiam sau (Vilnius, 1996).

ZAWADZKI, Wojciech. Losy franciszkanów w Prusach Zachodnich w okresie kasaty ich klasztorów, in: Hereditas monasteriorum 2 (Wrocław, 2013), pp. 95-107. 


\section{PASKUTINIAI KAUNO BERNARDINIŲ GYVAVIMO DEŠIMTMEČIAI (1842-1864)}

Santrauka

\section{VAIDA KAMUNTAVIČIENE்}

Straipsnyje atskleidžiamas Kauno Švč. Trejybès bernardinių gyvenimas 18421864 m., dèl Rusijos okupacinès valdžios politikos blogèjanti vienuolyno situacija, vienuolyno uždarymo procesas, nušviečiami vienuolių likimai po jo likvidavimo. Tyrimas atliktas pasinaudojant bernardinių susirašinèjimo su Žemaičių (Telšių) vyskupu Motiejumi Valančiumi ir vienuolynų vizitatoriumi Marcijonu Giedraičiu, M. Valančiaus atsiminimų, bernardinių vizitacijų medžiaga. Šis Kauno bernardinių atvejo tyrimas padeda geriau suvokti, kokia buvo Rusijos carinèje imperioje atsidūrusios Katalikų bažnyčios vienuolynų padètis.

Tyrimas atskleidè, kad $1842 \mathrm{~m}$. praradus fundacines valdas, iš valstybès iždo skiriamos pensijos nepakako, vienuolès bandè gauti giminaičių ar kitų pasaulietinių asmenų materialinę paramą. $1850 \mathrm{~m}$. buvo uždarytas Kauno šv. Jurgio bernardinų konventas, ligi tol globojęs vienuoles. Nors bernardinai liko gyventi prie bernardiniu kaip kapelionai, tačiau, susidūrę su nepritekliais, nepastebėjo ar nenorẻjo pastebėti bernardinių vienuolyną kamavusių problemų. Žemaiču vyskupas M. Valančius tapo pagrindiniu bernardinių globejju. Jis teisinosi gyvenęs toli nuo Kauno, Varniuose, netureję̧s galimybių iš arti stebėti vienuoliu gyvenimo. Problemų kilo dèl vienuolyno komplektacijos. Komplikavosi noviciato veikla, ị bernardinių bendruomenèje atsiradusias laisvas vietas paprastai buvo perkeliamos senyvo amžiaus vienuolès iš kitų vienuolynų. İvairios problemos darẻ ịtaką bernardinių tarpusavio santykiams, skatino pažeidinèti konstituciją, nesilaikyti klauzūros, ignoruoti neturtą, plètoti individualumą. Ištuštėjo bendruomeninio gyvenimo centras - refektorijus, bernardinès turejjo atskiras virtuves, po klauzūrinę teritoriją vaikščiojo pašaliniai asmenys, vienuolių giminaitės ar draugès. Taisydama bendruomenės negeroves, itin daug nuveikė vienuolyno vyresnioji Rožè Gružauskaitė. Nepaisant jos pastangų, $1864 \mathrm{~m}$. Kauno bernardinių vienuolynas buvo uždarytas, tuo metu ten gyvenusios bernardinès (iš viso 21) buvo išskirstytos po Kauno ir Kražių benediktinių, Krakių kotryniečių vienuolynus. Paskutinė Kauno bernardinė mirè Krakèse 1914 m. Šitaip pasibaigė Kauno bernardinių istorija, po vienuolyno uždarymo 1864 m. iki paskutinès vienuolès mirties užtrukusi dar 50 metų. 